\title{
Chemical modification studies of the active centre of Candida albicans chitinase and its inhibition by allosamidin
}

\author{
Slawomir Milewski, ${ }^{1 *}$ Raymond W. O’Donnell ${ }^{2}$ and Graham W. Gooday ${ }^{2}$ \\ ${ }^{1}$ Department of Pharmaceutical Technology and Biochemistry, Technical University of Gdansk, 80-952 Gdansk, Poland \\ ${ }^{2}$ Department of Molecular and Cell Biology, Marischal College, University of Aberdeen, Aberdeen AB9 IAS, UK
}

(Received 2 March 1992; revised 15 July 1992; accepted 28 August 1992)

\begin{abstract}
Allosamidin, a glycoside antibiotic, is shown to be a strong, competitive inhibitor of semi-purified chitinase from yeast cells of Candida albicans. The inhibitory potency of allosamidin was $\mathrm{pH}$-dependent, with $\mathrm{IC}_{50}$ values of $280 \mathrm{nM}$ at $\mathrm{pH} 5.0$ and $21 \mathrm{nM}$ at $\mathrm{pH}$ 7.5. At higher, micromolar, concentrations, allosamidin inactivated this chitinase in a time- and concentration-dependent manner. Kinetic studies of this inactivation provided evidence for the formation of a reversible complex between allosamidin and chitinase, characterized by $K_{\text {inact }}=5 \mu \mathrm{M}$, followed by irreversible modification of the enzyme with velocity constant $k_{2}=4.6 \times 10^{-3} \mathrm{~s}^{-1}$. Chemical modification studies with the use of group-specific reagents suggested the presence of Glu/Asp carboxyl group(s) at or near the active site, that were important for enzyme activity. The carboxyl-specific reagent, 1-ethyl-3(3-dimethylaminopropyl)-carbodiimide, inactivated the chitinase in a single step process, with apparent second-order rate constant of $0.014 \mathrm{M}^{-1} \mathrm{~s}^{-1}$.
\end{abstract}

\section{Introduction}

Chitinase is an enzyme of widespread occurrence with a wide range of roles (Gooday, 1991). In the yeast Saccharomyces cerevisiae, it is involved in separation of cells after budding (Kuranda \& Robbins, 1991; Cabib et al., 1992) and in filamentous fungi it is probably involved in hyphal growth and branching and in spore germination (Gooday et al., 1986; Rast et al., 1991). Chitinase activity has been described from yeast cells of the dimorphic human pathogenic fungus Candida albicans (Barrett-Bee \& Hamilton, 1984; Dickinson et al., 1989). Because of its roles in fungal growth, chitinase presents a target for potential anti-fungal agents. A specific inhibitor of some chitinases has recently been characterized, as a novel antibiotic from Streptomyces species, and has been named allosamidin (Sakuda et al., 1987) or A82516 (Somers et al., 1987). The chitinase from C. albicans is susceptible to allosamidin (Dickinson et al., 1989). We present here results of a study of the mode of action of the chitinase of $C$. albicans, as elucidated by the effects of selected group specific reagents and of allosamidin on a semi-purified preparation.

\footnotetext{
* Author for correspondence. Tel. (4858) 472523; fax (4858) 472694.
}

Abbreviations: EDC, 1-ethyl-3-(3-dimethylaminopropyl)-carbodiimide; (GlcNAc) $)_{2}, N$ - $N^{\prime}$-diacetylchitobiose; $(\mathrm{GlcNAc})_{3}, N-N^{\prime}-N^{\prime \prime}$ triacetylchitotriose; (GlcNAc) $4, N, N^{\prime}, N^{\prime \prime}, N^{\prime \prime \prime}$-tetraacetylchitotetaose; MeUmb, 4-methylumbelliferyl; $\mathrm{p}$-CIMB, parachloromercuribenzoate.

\section{Methods}

Preparation of semi-purified enzyme. C. albicans strain 2005E (Glaxo Group Research) was grown as yeast cells in Sabouraud's dextrose broth (Oxoid) at $37^{\circ} \mathrm{C}$ in conical flasks, shaking at 200 r.p.m., using overnight, late lag phase cultures as inocula. Cultures were harvested after $6 \mathrm{~h}$ by centrifugation at $10000 \mathrm{~g}$ for $5 \mathrm{~min}$ at $4^{\circ} \mathrm{C}$. The cells were washed in ice-cold $20 \mathrm{~mm}$-citrate $/ 40 \mathrm{~mm}$-phosphate buffer $\mathrm{pH} 6.0$ and re-centrifuged. The cells were homogenized in a Braun MSK cell disintegrator with an equal volume of $0.45 \mathrm{~mm}$ glass beads. The homogenate was centrifuged at $20000 \mathrm{~g}, 5 \mathrm{~min}, 4^{\circ} \mathrm{C}$, to remove cell debris and unbroken cells, and this supernate was re-centrifuged at $105000 \mathrm{~g}, 1 \mathrm{~h}, 4^{\circ} \mathrm{C}$, to yield a supernatant preparation. This was subjected to ammonium sulphate precipitation at $0{ }^{\circ} \mathrm{C}$. Precipitates below $65 \%$ ammonium sulphate saturation were discarded; those between 65 and $95 \%$ were redissolved in the citrate/phosphate buffer and pooled. This preparation was equilibrated in $20 \mathrm{~mm}$-piperazine buffer, pH 5.7, in a fast desalting column (Sephadex G-25 Superfine) with an FPLC system (Pharmacia) and subjected to anion exchange chromatography in the same buffer using a Mono Q HR5/5 column with the FPLC system. Elution was with a linear gradient of increasing $\mathrm{NaCl}$ concentration, from zero to $0.6 \mathrm{M}$ in buffer at a flow rate of $0.5 \mathrm{ml} \mathrm{min}{ }^{-1}$. Active fractions, eluting at $0.08-0.1 \mathrm{M}-\mathrm{NaCl}$, showed a 30-fold purification over the original cytoplasmic extract, with a specific activity of 16.5 pkat (mg protein $)^{-1}$, and were used as the semipurified preparation for these studies.

Standard assay of chitinase activity. Activity was assayed in microtitre plates using a fluorogenic method (McCreath \& Gooday, 1992) with 4methylumbelliferyl- $N, N^{\prime}, N^{\prime \prime}, N^{\prime \prime \prime}$-chitotetraoside [MeUmb(GlcNAc) $\left.{ }_{4}\right]$ as substrate. Incubation mixtures contained $0.1 \mathrm{ml}$ enzyme solution in an appropriate buffer, $0.05 \mathrm{ml} 80 \mu \mathrm{M}-\mathrm{MeUmb}(\mathrm{GlcNAc})_{4}$ and $0.05 \mathrm{ml}$ of buffer or inhibitor solution in buffer. After prewarming all the components to $37^{\circ} \mathrm{C}$, the reaction was started by adding the enzyme 
solution. After $30 \mathrm{~min}$ incubation at $37^{\circ} \mathrm{C}, 0.05 \mathrm{ml} 5 \mathrm{M}-\mathrm{NaOH}$ was added to each well to stop the reaction. Fluorescence was measured immediately in the spectrofluorimeter at excitation band $363 \mathrm{~nm}$ and absorption band $440 \mathrm{~nm}$. The concentration of MeUmb released was read from the standard curve. Protein was assayed by the method of Bradford (1976) with BSA as a standard.

Determination of kinetic parameters of inhibition. Initial velocities of chitinase-catalysed hydrolysis of $\mathrm{MeUmb}(\mathrm{GlcNAc})_{4}$ were determined by continuous monitoring of MeUmb release, in samples containing various concentrations of the substrate $(1.25-20 \mu \mathrm{M})$ and allosamidin $(0-300 \mathrm{nM})$. Lineweaver-Burk plots were constructed using least square method.

Inactivation of chitinase by allosamidin and chemical modification of the enzyme. Chemical modifications of chitinase were performed using a variety of group-selective reagents and allosamidin. Buffers for incubation mixtures were chosen to ensure optimal conditions of inactivation, according to literature data: chemical modification by thiol-binding reagents and by PMSF was performe 1 in 0.1 M-PIPES, $\mathrm{pH} 7.5$; participation of histidine residues was investigated by treatment with diethylpyrocarbonate in $0.1 \mathrm{M}-\mathrm{MES}$, pH 6.0 ; phenylglyoxal was used as an agent specifically reacting with the guanidyl group of arginine, in $0.1 \mathrm{M}$-PIPES, pH 6.0; modification of the carboxyl group of Asp/Glu residues was performed using EDC in 0.1 M-MES, pH 6.0; inactivation by allosamidin was studied in different buffer systems but optimal conditions were achieved in 0.1 M-PIPES, pH 7.5.

In all inactivation experiments, $1 \mu \mathrm{g}$ of enzyme protein containing the semi-purified chitinase was incubated at $25^{\circ} \mathrm{C}$ in buffer, with a given inactivator at appropriate concentration (total volume $1 \mathrm{ml}$ ). The gel-filtration-centrifuge method (Penefsky, 1977) was used to follow the inactivation, as follows: $0.2 \mathrm{ml}$ samples of incubation mixtures were periodically withdrawn and applied at tops of $1 \mathrm{ml}$ columns packed with Sephadex G-50 (previously equilibrated with an appropriate buffer) and centrifuged ( $1 \mathrm{~min}, 200 \mathrm{~g}$ ). Under these conditions the unbound inhibitor was separated from the enzyme and the protein was recovered in clean test tubes. Appropriate effluent samples were used for the determination of the residual enzyme activity by using the standard assay method. The efficiency of this technique for the separation of protein from unbound inhibitor was tested by three methods. (i) Three samples of $0.2 \mathrm{ml}$ of a solution containing Ellman's reagent $(100 \mu \mathrm{M})$ and BSA $\left(100 \mu \mathrm{g} \mathrm{ml}^{-1}\right)$ were treated as described. Under these conditions, Ellman's reagent was retained in the gel bed as a clearly visible narrow yellow band just below the top of the gel. The protein concentrations of the eluates were $100 \pm 3 \mu \mathrm{g} \mathrm{ml}^{-1}$. (ii) Samples of $0.2 \mathrm{ml}$ of a solution of allosamidin $(10 \mu \mathrm{M})$ and BSA $\left(100 \mu \mathrm{g} \mathrm{ml}^{-1}\right)$ were treated as described. The possible presence of allosamidin in the eluates was tested by assaying for inhibition of chitinase $(\mathrm{pH} 7 \cdot 5,0.1 \mathrm{M}-$ PIPES buffer). No inhibition was observed, while in a simultaneous experiment, $1 \mathrm{nM}$-allosamidin in the presence of BSA $\left(100 \mu \mathrm{g} \mathrm{ml}^{-1}\right)$ gave $40 \pm 3 \%$ inhibition of chitinase activity. BSA alone did not affect chitinase activity. (iii) Protein present in the chitinase preparation was recovered with $100 \%$ efficiency after treatment as described.

\section{Results}

$\mathrm{MeUmb}(\mathrm{GlcNAc})_{4}$ was chosen as a soluble substrate for determination of $C$. albicans chitinase activity. The enzyme exhibited much higher activity towards this substrate than towards other $\mathrm{MeUmb}(\mathrm{GlcNAc})_{\mathrm{n}}$ oligomers (dimer, trimer). This suggests that its major

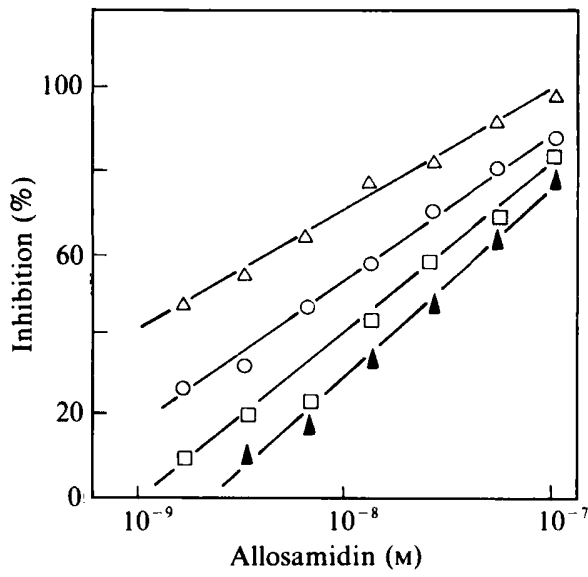

Fig. 1. Inhibitory effect of allosamidin against $C$. albicans chitinase at different $\mathrm{pH}$ values. Incubation mixtures contained enzyme protein $\left(1 \mu \mathrm{g} \mathrm{ml}^{-1}\right), \mathrm{MeUmb}(\mathrm{GlcNAc})_{4}(20 \mu \mathrm{M})$, allosamidin $(0-100 \mathrm{nM})$ and $0.1 \mathrm{M}$-PIPES buffer ( $\mathrm{pH}$ as indicated below) in total volumes of $0.2 \mathrm{ml}$, in wells of a microtitre plate. The reaction was initiated by adding the enzyme solution. After $30 \mathrm{~min}$ incubation at $37^{\circ} \mathrm{C}$, the reaction was stopped by adding $0.05 \mathrm{ml} 5 \mathrm{M}-\mathrm{NaOH}$ to each well and the fluorescence was measured immediately. $\Delta, \mathrm{pH} \mathrm{5.0;} \square, \mathrm{pH} 6.0 ; 0, \mathrm{pH} \mathrm{6.5}$; $\triangle, \mathrm{pH} 7 \cdot 5$.

activity is as an endochitinase (cf. McCreath \& Gooday, 1992). It had no effect on MeUmb-GlcNAc, so had no $N$-acetylglucosaminidase activity. Using $\mathrm{MeUmb}(\mathrm{GlcNAc})_{4}$, we confirmed the strong inhibitory potency of allosamidin against this enzyme. The effectiveness of this inhibition was dependent on pH (Fig. 1). The $\mathrm{IC}_{50}$ value at $\mathrm{pH} 7.5$ was several-fold lower than that at pH 5.0 (21 nM and $280 \mathrm{nM}$, respectively). The mode of inhibition was competitive with inhibition constants as low as $10 \mathrm{nM}$ in $0.1 \mathrm{M}$-PIPES, $\mathrm{pH} 7.5$ and $62.5 \mathrm{~nm}$ in $0 \cdot 1$ M-PIPES, pH 6.0 (Fig. 2). Similar values and inhibition were obtained in MES and phosphate buffers. Surprisingly, results obtained in McIlvaine's citrate/ phosphate buffer suggested mixed or even non-competitive mode of inhibition (data not shown).

Incubation of partially purified chitinase with allosamidin in the absence of substrate led to the irreversible inactivation of the enzyme. Allosamidin $(10 \mu \mathrm{M})$ inactivated chitinase completely after $20 \mathrm{~min}$ incubation. The time course of inactivation is shown in Fig 3. The irreversibility of this phenomenon was shown by incubating chitinase $\left(1 \mu \mathrm{g} \mathrm{ml}^{-1}\right)$ with allosamidin $(10 \mu \mathrm{M})$ for $30 \mathrm{~min}$ at $37^{\circ} \mathrm{C}$, isolating the allosamidinenzyme complex by the gel-filtration-centrifuge method, reincubating this for a further $30 \mathrm{~min}$ at $37^{\circ} \mathrm{C}$, and then subjecting it to a further cycle of the gel-filtrationcentrifugation procedure. There was no recovery of chitinase activity. When values of apparent rate constants of inactivation $\left(k_{\mathrm{app}}\right)$, calculated from the slope of lines in Fig. 3, were plotted against allosamidin 


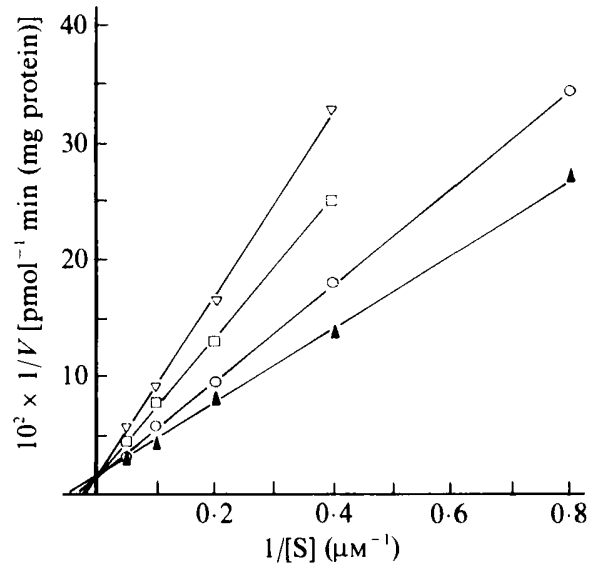

Fig. 2. Inhibition of chitinase by allosamidin. Incubation mixtures consisted of the enzyme protein $\left(1 \mu \mathrm{g} \mathrm{ml}^{-1}\right), \mathrm{MeUmb}(\mathrm{GlcNAc})_{4}$ $(0-20 \mu \mathrm{M})$ and allosamidin $(\Delta, 0 \mathrm{nM} ; O, 25 \mathrm{nM} ; \square, 50 \mathrm{nM} ; \nabla, 100 \mathrm{nM})$ in $0.2 \mathrm{ml}$ portions of $0.1 \mathrm{M}$-PIPES buffer, $\mathrm{pH} \mathrm{6.0.The} \mathrm{reaction} \mathrm{was} \mathrm{carried}$ out, stopped and the fluorescence measured as described in the legend to Fig. 1. The results were plotted as $1 / V$ versus $1 /[\mathrm{S}]$. All points are the average of three determinations.

concentration, a hyperbolic curve was obtained (not shown). Such a pattern is consistent with the formation of a reversible complex before inactivation:

$$
\mathrm{E}+\mathrm{I} \underset{k_{-1}}{\stackrel{k_{1}}{\rightleftharpoons}}\left[\mathrm{E}^{*} \mathrm{I}\right] \stackrel{k_{2}}{\rightarrow} \mathrm{EI}^{*}
$$

[E*I] is the enzyme-inhibitor complex and $\mathrm{EI}^{*}$ is the irreversibly modified enzyme.

Assuming that $[I] \gg[E]$ and that the reversible complex is at all times in equilibrium with enzyme and inhibitor, the equation derived by Meloche (1967) can be applied:

$$
\tau=\frac{1}{[\mathrm{I}]}\left(\mathrm{T} \cdot K_{\text {inact }}+\mathrm{T}\right.
$$

where $K_{\text {inact }}$ is the inactivation constant, $\tau$ is a particulate half-time of inactivation and $T$ is the minimal inactivation half-time at infinite inhibitor concentration.

Values of $K_{\text {inact }}, T$ and $k_{2}$ were calculated from a linear plot of inactivation half-times versus reciprocal of allosamidin concentration (Fig. 4). The values obtained were:

$$
K_{\text {inact }}=5 \mu \mathrm{M} ; \mathrm{T}=2.5 \min ; k_{2}=\frac{\ln 2}{\tau}=4.6 \times 10^{-3} \mathrm{~s}^{-1}
$$

The calculated value of apparent second-order rate constant $\left(k_{2} / K_{\text {inact }}\right)$ was $0.92 \times 10^{3} \mathrm{M}^{-1} \mathrm{~s}^{-1}$, i.e. much lower than $k_{1}$ (commonly at least $10^{7} \mathrm{M}^{-1} \mathrm{~s}^{-1}$ for substrates). Therefore the quasi-equilibrium assumption for the kinetic two-step model of inactivation is fully justified (Brocklehurst, 1979).

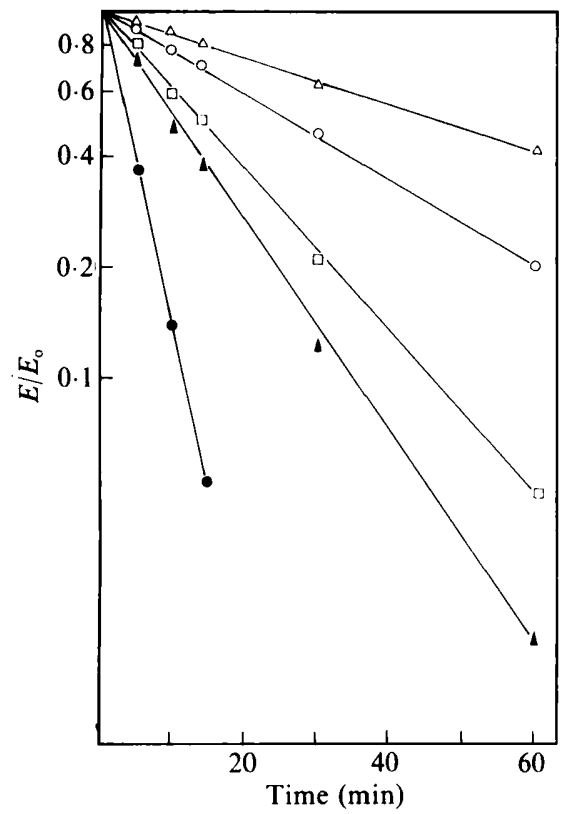

Fig. 3. Time course of inactivation of chitinase by allosamidin. Enzyme protein $\left(1 \mu \mathrm{g} \mathrm{ml}^{-1}\right)$ was incubated with allosamidin $(\triangle$, $0.25 \mu \mathrm{M} ; O, 0.5 \mu \mathrm{M} ; \square, 1.0 \mu \mathrm{M} ; \Delta, 2.0 \mu \mathrm{M} ; \bullet, 10 \mu \mathrm{M})$ in PIPES buffer, pH 7.5 (total vol. $1 \mathrm{ml}$ ). Samples $(0.2 \mathrm{ml})$ were periodically withdrawn, applied to the tops of columns packed with Sephadex G-50, and centrifuged. The residual enzyme activity was assayed in effluent samples by the fluorimetric method.

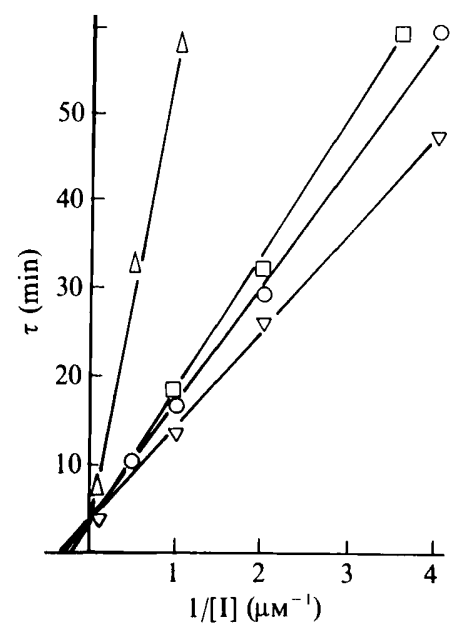

Fig. 4. Protective effect of (GlcNAc) $)_{n}$ oligomers against allosamidinmediated inactivation of chitinases. Mixtures containing enzyme protein $\left(1 \mu \mathrm{g} \mathrm{ml}^{-1}\right)$, allosamidin and (Glc NAc) oligomers $(1 \mathrm{mM})$ were incubated at $25^{\circ} \mathrm{C}$. Samples $(0.2 \mathrm{ml})$ were periodically withdrawn and treated as described in the legend to Fig. 3. Data obtained from the time course of inactivation (not shown) were plotted as $\tau=f(1 /[I])$. $\nabla$, allosamidin alone; $\triangle, \quad$ allosamidin $+(\mathrm{GlcNAc})_{4} ; \quad \square$, allosamidin $+(\text { GlcNAc })_{3} ;$ O, allosamidin $+(\text { GlcNAc })_{2}$.

The same graph shows the protection of chitinase against inactivation by allosamidin provided by short (GlcNAc) $)_{n}$ oligomers. The protective effect of $(\mathrm{GlcNAc})_{4}$ was much stronger than those of $(\mathrm{GlcNAc})_{2}$ and (GlcNAc) $)_{3}$. GlcNAc had no effect (not shown). 
Table 1. Chemical modification of C. albicans chitinase by group-specific reagents

Values of $\%$ inactivation are the means of three independent determinations. SD in each case was $\pm 3 \%$.

\begin{tabular}{lll}
\hline \hline \multicolumn{1}{c}{ Group } & \multicolumn{1}{c}{ Reagent } & \multicolumn{1}{c}{ Inactivation } \\
\hline 1. -SH (Cys) & Iodoacetic acid (10 mM) & $46 \%$ after $30 \mathrm{~min}$ \\
& Iodoacetamide (10 mM) & $52 \%$ after $30 \mathrm{~min}$ \\
& p-ClMB (5 mM) & $58 \%$ after $30 \mathrm{~min}$ \\
& $N$-Ethylmaleimide $(10 \mathrm{mM})$ & $30 \%$ after $30 \mathrm{~min}$ \\
2. -OH (Ser/Thr) & PMSF (1 mM) & None \\
3. -guanidyl (Arg) & Phenylglyoxal $(50 \mathrm{mM})$ & None \\
4. -imidazoyl (His) & Diethylpyrocarbonate & None \\
5. -carboxyl (Glu/Asp) & EDC & Dependent on time and concentration \\
\hline \hline
\end{tabular}

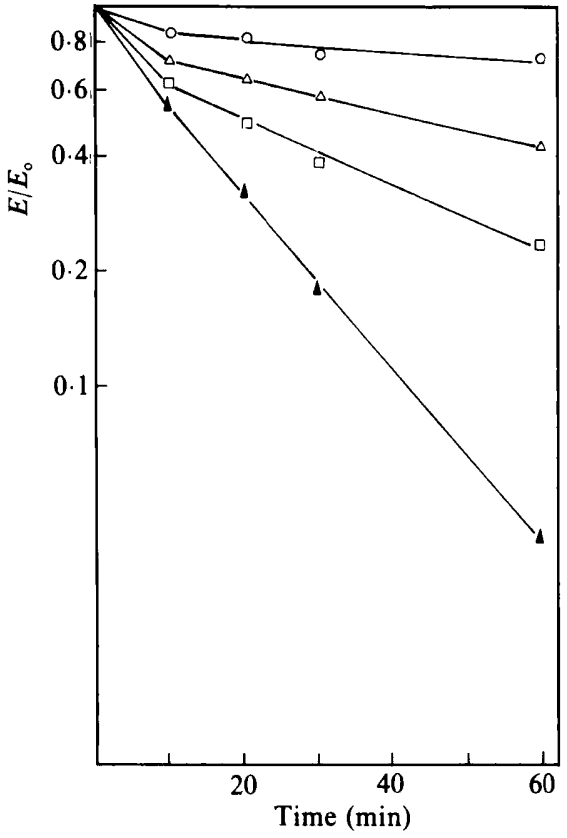

Fig. 5. Time course of inactivation of chitinase by EDC. Enzyme protein $\left(1 \mu \mathrm{g} \mathrm{ml}^{-1}\right)$ was incubated with $\operatorname{EDC}(0,6.25 \mathrm{mM} ; \triangle, 12.5 \mathrm{mM}$; 口, $25 \mathrm{~mm} ; \Delta, 50 \mathrm{mM}$ ) in $0.1 \mathrm{M}$-MES buffer, $\mathrm{pH} 6.0$. Other conditions were as in the legend to Fig. 3.

Several group-specific chemical reagents were used to investigate amino acids at the active site of chitinase. The results of these studies are summarized in Table 1. Most of the agents used failed to inactivate the enzyme. Partial inactivation was observed with thiol-blocking reagents, but this effect was seen only at very high concentrations. On the other hand, time- and concentration-dependent inactivation by the carboxyl-specific carbodiimide derivative EDC was demonstrated. Semilogarithmic plots of residual activity as a function of time were biphasic, indicating complexity of the EDCinduced inactivation (Fig. 5). However, after resolving into two first-order processes, the slope at longer times,

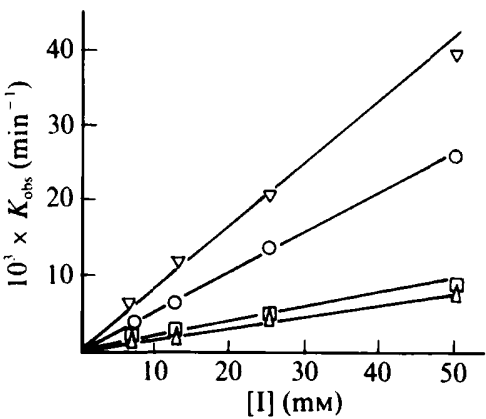

Fig. 6. Protective effect of (GlcNAc) oligomers against EDCmediated inactivation of chitinase. Mixtures containing enzyme protein $\left(1 \mu \mathrm{g} \mathrm{m}^{-1}\right)$, EDC and (GlcNAc) oligomers (1 mM) were incubated at $25^{\circ} \mathrm{C}$ in $0.1 \mathrm{M}$-MES buffer, pH 6.0. Inactivation was followed as described in the legend to Fig. 3. Data obtained from the time course of inactivation (not shown) were plotted as $k_{\text {obs }}$ versus EDC concentration. $\nabla$, EDC alone; O, EDC $+(\text { GlcNAc })_{2} ; \square$, $\mathrm{EDC}+(\mathrm{GlcNAc})_{3} ; \triangle, \mathrm{EDC}+(\mathrm{GlcNAc})_{4}$.

obviously determining the rate of inactivation, could be used for calculation of apparent pseudo-first-order constants. A plot of these constants against EDC concentration was linear (Fig. 6) and provided a secondorder rate constant of $14 \times 10^{-3} \mathrm{M}^{-1} \mathrm{~s}^{-1}$. Analysis of the order of inactivation with respect to EDC concentration by the method of Levy et al. (1963) yielded a slope of 0.91 (not shown), indicating that one molecule of EDC binds to one molecule of enzyme when inactivation occurs.

(GlcNAc) $)_{n}$ oligomers protected chitinase against inactivation by EDC (Fig. 6). However, in this case, (GlcNAc) ${ }_{3}$ was nearly as good as (GlcNAc) ${ }_{4}$ as a protective agent; both were much better than $(\text { GlcNAc })_{2}$.

\section{Discussion}

Allosamidin, a pseudo-trisaccharide containing $\mathrm{N}$ acetylallosamine (Sakuda et al., 1987; Somers et al., 1987), is a strong inhibitor of chitinases from the insect 
Bombyx mori (Koga et al., 1987), the nematode Onchocerca gibsoni (Gooday et al., 1988), the fungi Neurospora crassa (McNab \& Glover, 1991) and S. cerevisiae (Cabib et al., 1992) and yeast Kluyveromyces lactis toxin (Butler et al., 1991). It has poorer activity against bacterial chitinases (Sakuda et al., 1987; Somers et al., 1987; Koga et al., 1987) and no detectable activity against the plant chitinase from yam (Koga et al., 1987). This antibiotic was also shown to be a competitive inhibitor of C. albicans chitinase, in studies with the use of tritiated chitin as a substrate (Dickinson et al., 1989). In this work we confirmed the inhibitory potency of allosamidin, using the soluble substrate $\mathrm{MeUmb}(\mathrm{GlcNAc})_{4}$. The mode of inhibition depended on the buffer system, being competitive in phosphate, MES and PIPES buffers but mixed or even non-competitive in citrate/phosphate buffer. It should be noted that although most reports have described a competitive mode of chitinase inhibition by allosamidin, there is also a report showing uncompetitive inhibition of the enzyme from Neurospora crassa (McNab \& Glover, 1991). Unfortunately we did not find any correlation which could explain these variations. The $C$. albicans chitinase was irreversibly inactivated by allosamidin in the absence of substrate. Since this phenomenon was observed at much higher concentrations of the antibiotic than inhibition, these two processes are probably independent. The inactivation fulfilled most of the criteria formulated for activesite-directed, covalent enzyme modification (Marletta \& Kenyon, 1979): inactivation was complete at appropriate inhibitor concentration; enzyme activity did not return upon gel filtration; inactivation obeyed saturation kinetics and substrates [in this case (GlcNAc) oligomers] protected the enzyme against inactivation. The stoichiometry of chitinase : allosamidin interaction was not determined; it should be $1: 1$ if the inhibitor is to be considered an active-site-directed agent. Nevertheless, the structural analogy between allosamidin and $(\mathrm{GlcNAc})_{\mathrm{n}}$ oligomers - good substrates for chitinase makes this assumption very likely.

Since the allosamidin-chitinase adduct was not isolated and its structure not determined, one can only speculate about the possible mechanism of inactivation. The aminocylitol part of allosamidin may well behave as an isourea derivative and therefore act as an alkylating agent. If so, a covalent bond could be formed with any nucleophilic residue at the enzyme active site. Currently, little is known of the active site of chitinase. Chemical modification studies could provide some evidence for the possible participation of particular amino acids in catalytic action. Data presented in this work exclude the presence of serine, histidine and arginine at the active site of chitinase. On the other hand, it seems very likely that Glu/Asp carboxyl group(s) play an important role in the catalytic centre of the enzyme. Such a situation is common among other glycosidases like lysozyme (Lin \& Koshland, 1969), $\beta$-glucosidase (Clarke, 1990) and cellulase (Moranelli et al., 1986). By hydrophobic cluster analysis of amino acid sequences from a range of plant and bacterial chitinases, Henrissat (1990) reports the presence of four invariant acid residues, three aspartate and one glutamate, in the putative active-site region. Further analysis of more sequences (B. Henrissat, personal communication) has reduced the number of putative catalytic residues to two, an aspartate and a glutamate. Recently Kuranda \& Robbins (1991) cloned and sequenced chitinase from $S$. cerevisiae. By comparison with other chitinase sequences, these authors also suggested the presence of the three aspartate and one glutamate residues in the catalytic domain of this enzyme. Since $C$. albicans and $S$. cerevisiae are related micro-organisms, one should expect a high extent of homology in sequences of respective enzymes.

The $S$. cerevisiae chitinase also has a chitin-binding domain, rich in cysteine residues (Kuranda \& Robbins, 1991). We observed the partial inactivation of C. albicans chitinase by thiol-blocking reagents. Since the substrate used by us for the determination of enzyme residual activity is shorter than natural chitin chains, it is possible that blocking of the cysteine residues at the binding domain does not prevent $\mathrm{MeUmb}(\mathrm{GlcNAc})_{4}$ from gaining access to the catalytic site. In any case, high concentrations of thiol reagents necessary for the partial inactivation of chitinase exclude the participation of any cysteine residue in the catalytic action of the enzyme. It should be added that some other chitinases have been reported to be inhibited by $\mathrm{Hg}^{2+}$ ions (Somers et al., 1987) and iodoacetic acid (Yabuki et al., 1986). Both these agents are known as thiol-blocking compounds. However, divalent metal ions are also able to form stable complexes with carboxylic groups at the active sites of enzymes (Perkins et al., 1979). On the other hand, halogeno derivatives of aliphatic carboxylic acids have been reported to alkylate nucleophilic carboxylate anions, as was shown in bromopyruvate mediated inactivation of aldolase (Vlahos \& Dekker, 1990).

We thank the Nuffield Foundation for support for S. M. R.W.O'D was a recipient of a CASE Research Studentship from the Science and Engineering Research Council with Glaxo plc. We thank Professor A. Suzuki for the sample of allosamidin.

\section{References}

Barrett-BeE, K. \& Hamilton, M. (1984). The detection and analysis of chitinase activity from the yeast form of Candida albicans. Journal of General Microbiology 130, 1857-1861.

BRADFORD, M. M. (1976). A rapid and sensitive method for the quantitation of microgram quantities of protein using the principle of protein-dye binding. Analytical Biochemistry 72, 248-254. 
BroCKLEHURST, K. (1979). The equilibrium assumption is valid for the kinetic treatment of most time-dependent protein-modification reactions. Biochemical Journal 181, 775-778.

Butler, A. R., O'Donnell, R. W., Martin, V. J., Gooday, G. W. \& STARK, M. J. R. (1991). Kluveromyces lactis toxin has an essential chitinase activity. European Journal of Biochemistry 199, 483-488.

Cabib, E., Silverman, S. J. \& Shaw, J. A. (1992). Chitinase and chitin synthase 1: counterbalancing activities in cell separation of Saccharomyces cerevisiae. Journal of General Microbiology 138, 97-102.

Clarke, A. J. (1990). Chemical modification of a $\beta$-glucosidase from Schizophyllum commune; evidence for essential carboxyl groups. Biochimica et Biophysica Acta 1040, 145-152.

Dickinson, K., KeER, V., HitchCock, C. A. \& AdAMs, D. J. (1989). Chitinase activity from Candida albicans and its inhibition by allosamidin. Journal of General Microbiology 135, 1417-1421.

Gooday, G. W. (1991). The physiology of microbial degradation of chitin and chitosan. Biodegradation 1, 177-190.

Gooday, G. W., Humphreys, A. M. \& McINTOSH, W. H. (1986). Roles of chitinase in fungal growth. In Chitin in Nature and Technology, pp. 83-91. Edited by R. A. A. Muzzarelli, C. Jeuniaux, \& G. W. Gooday. New York: Plenum Press.

GoOdAy, G. W., BRYdon, L. J. \& Chappell, L. H. (1988). Chitinase in female Onchocerca gibsoni and its inhibition by allosamidin. Molecular and Biochemical Parasitology 29, 223-225.

HeNRisSaT, B. (1990). Weak sequence homologies among chitinases detected by clustering analysis. Protein Sequence and Data Analysis 3, 523-526.

Koga, D., Isogai, A., Sakuda, S., Matsumoto, S., Suzuki, A., KimurA, S. \& IDE, A. (1987). Specific inhibition of Bombyx mori chitinase by allosamidin. Agricultural and Biological Chemistry 51, 471-476.

KuRANDA, M. J. \& Robbins, P. W. (1991). Chitinase is required for cell separation during growth of Saccharomyces cerevisiae. Journal of Biological Chemistry 266, 19758-19767.

LEVY, H. M., LEBER, P. D. \& RYAN, E. M. (1963). Inactivation of myosin by 2,4-dinitrophenol and protection by adenosine triphosphate and other phosphate compounds. Journal of Biological Chemistry 238, 3654-3659.

LIN, T. Y. \& Koshland, D. E., JR. (1969). Carboxyl group modification and the activity of lysozyme. Journal of Biological Chemistry 244, 505-508.

MCCreath, K. \& GoOday, G. W. (1992). A rapid and sensitive micro assay for determination of chitinolytic activity. Journal of Microbiological Methods 14, 229-237.

MCNAB, R. \& Glover, L. A. (1991). Inhibition of Neurospora crassa cytosolic chitinase by allosamidin. FEMS Microbiology Letters 82 , $79-82$.

Marletta, M. A. \& Kenyon, K. L. (1979). Affinity labelling of creatine kinase by (2,3-epoxypropyl)- $N$-amidinoglycine. Journal of Biological Chemistry 254, 1879-1886.

Meloche, H. P. (1967). Bromopyruvate inactivation of 2-keto-3deoxy-6-phosphogluconic aldolase. I. Kinetic evidence for active site specificity. Biochemistry 6, 2273-2280.

Moranelli, F., Barbier, J. R., Dove, M. J., Mackay, R. M. \& SELigy, V. L. (1986). A clone coding for Schizophyllum commune $\beta$-glucosidase. Biochemistry International 12, 905-912.

PenEFSKY, H. S. (1977). Reversible binding of inorganic phosphate by beef heart mitochondrial adenosine phosphatase. Journal of Biological Chemistry 252, 2891-2899.

Perkins, S. J., Johnson, L. N., Machin, P. A. \& Phillips, D. C. (1979). Crystal structures of egg-white lysozyme of hen in acetatefree medium and of lysozyme complexes with $N$-acetylglucosamine and $\beta$-methyl- $N$-acetylglucosaminide. Biochemical Journal. 181, $21-36$.

Rast, D. M., Horsch, M., Furter, R. \& Gooday G. W. (1991). A complex chitinolytic system in exponentially growing mycelium of Mucor rouxii: properties and functions. Journal of General Microbiology 137, 2797-2810.

Sakuda, S., Isogai, A., Matsumoto, S. \& Suzuki, A. (1987). Search for microbial insect growth regulators II. Allosamidin, a novel insect chitinase inhibitor. Journal of Antibiotics 40, 296-300.

Somers, P. J. B., Yao, R. C., Doolin, L. R., McGowan, M. J., FAKUDA, D. S. \& MYNDERSE, J. S. (1987). Method for the detection and quantitation of chitinase inhibitors in fermentation broths: isolation and insect life cycle. Effect of A82516. Journal of Antibiotics 40, $1751-1756$.

Vlahos, C. J. \& DekKer, E. E. (1990). Active site residues of 2-keto-4hydroxyglutarate aldolase from Escherichia coli. Bromopyruvate inactivation and labelling of glutamate 45. Journal of Biological Chemistry 265, 20384-20389.

Yabuki, M., Mizushina, K., Amatatsu, T., Ando, A., Fuji, T., Shimada, M. \& Yamashita, M. (1986). Purification and characterisation of chitinase and chitobiase produced by Aeromonas hydrophila subsp. anaerogenes A52. Journal of Applied and General Microbiology 32, 25-38. 